\title{
SHOULD THE HOLOCAUST FORCE US TO RETHINK OUR VIEW OF GOD AND EVIL?
}

\author{
John J. Johnson
}

\section{Summary}

This paper grapples with the impact the Holocaust has had on JewishChristian relations, and comes to the conclusion that the problem of evil is an age-old dilemma for biblical theists, and does not take on special meaning in light of the Holocaust (even though that was indeed a horrific event). The Holocaust must be seen in proper perspective, alongside all the many other large-scale atrocities which have occurred throughout history. The Holocaust raises the same issues as are found in the Book of Job, though the proper response is not a radical rethinking of Christian theology but, as Job long ago discovered, a humble, biblical acceptance of the limits of human understanding when faced with apparently pointless suffering.

By all accounts, the Holocaust was a nearly unimaginable example of human depravity, which caused an unimaginable amount of human suffering. The so-called problem of evil, which had vexed theists for so long, was perhaps never as startlingly apparent as it was in the gas chambers and the ovens of the Nazi death-camps. Ever since that horrendous event, many Jews have found it impossible to hold onto a faith which, for them, vanished in the ovens of Auschwitz. This position is well-exemplified in the fiction of Holocaust survivor, Elie Wiesel. The following lines from his short autobiographical novel well capture the spirit of much contemporary Jewish thought, both popular and scholarly, regarding the Holocaust. Wiesel describes his reaction to the pious prayers of his fellow inmates in the death-camps:

... why should I bless Him [God]? In every fiber I rebelled. Because He had had thousands of children burned in His pits? Because He kept the crematories working night and day, on Sundays and feast days? Because in His great might He had created Auschwitz, Birkenau, Buna, and so many factories of death? How could I say to Him: 'Blessed art Thou, Eternal, Master of the Universe, Who chose us from among the races to be tortured day and night, to see our fathers, our mothers, our brothers, end in the 
crematory? Praised be Thy Holy Name, Thou Who hast chosen us to be butchered on Thine altar?'l

Many Christian thinkers have followed suit, and, after reflecting upon the Holocaust, are prepared to recast essential Christian doctrines in response to the horrors of the death-camps. In this paper, I hope to address Jews and Christians who hold such views because they feel compelled to do so in light of the tragedy of the Holocaust. My contention is that the real problem at hand is not the Holocaust per se, but rather the apparently pointless evil which falls on humanity in general. I aim to show that such Holocaust-inspired revisionist theology is not only unfaithful to scripture, but especially fails to address adequately the real problem at the heart of the Holocaust, as well as many other human tragedies. That problem is the seemingly random evil which plagues humanity in a world that, according to scripture, was created by an all-loving, omnipotent God. Unless we allow, as does the author of the book of Job, that evil ultimately is an impenetrable mystery which must be accepted in humble faith, no revisionist theology of human suffering is satisfactory.

Long before the Holocaust, Christian (and non-Christian) thinkers anticipated the themes which run through much of post-Holocaust Jewish theology. This of course reinforces my position that it is the general problem of evil, not the specific example which the world witnessed in the Holocaust, which is at the root of the problem. One need only think of Dostoyevsky's Brothers Karamazov. In it, the atheist, Ivan, does not reject God because he finds God's existence implausible, as would a Hume, who rejects God on philosophical grounds, or a modern-day evolutionary reductionist, who simply sees no need for an imagined deity when science alone can account for all things in our universe. No, Ivan can accept the idea of God's existence, but that existence is not compatible with the world God has made. He tells his brother Aloysha that, 'Its not that I don't accept God, you must understand, its the world created by Him I don't and cannot accept.'2 It is the world with all its apparent needless suffering, especially the suffering of young children, which causes Ivan to reject the Christianity of his brother Aloysha. He goes on to recount atrocities committed by Turks in Bulgaria, who toss 'babies up in the air and [catch] them on the points of their bayonets before their

I Elie Wiesel, Night, (New York: Bantam Books, 1982), 64.

2 Fyodor Dostoyevsky, The Brothers Karamazov (ET Constance Garnett; New York: Random House, 1950), 279. 
mother's eyes.' ${ }^{3}$ Ivan understands that adults are sinful, and he is able to accept a God who punishes them for their sins, but such atrocities committed against those who have not yet had time to earn the title 'sinner' are impossible to reconcile with his Christian brother's idea of a loving God. Ivan's solution to the dilemma is, of course, atheism, but it is not really a solution at all, at least not for the Jew or Christian who believes in an omnipotent God and is struggling to reconcile that belief with human suffering. (Even for Ivan, atheism is no real solution, for it indirectly brings about the murder of Ivan's father at the hands of Ivan's half-brother, Smerdyakov, who uses Ivan's radical notions as justification for his crime).

When we turn to the theological realm, we find a much different view of the relationship between God and evil in the classic theodicy of John Hick, Evil and the God of Love. After surveying traditional explanations of evil vis-à-vis God as espoused by such representative thinkers as Augustine and Calvin, Hick finds them unacceptable. Again, it is the awful reality of evil, the same stumbling block which prevented Ivan from accepting the 'God of Love' his brother so firmly trusted in. 'The enigma of evil presents so massive and direct a threat to our faith that we are bound to seek within the resources of Christian thought for ways, if not of resolving it, at least of rendering it bearable by the Christian conscience.' ' 4 Hick rejects the 'Augustinian' theodicy (which places the blame for evil on Satan and/or fallen man) and instead offers an 'Irenaean' theodicy which he refers to as 'soulbuilding'. Basically, Hick's premise is that God allows evil in order that his creatures may develop moral and spiritual strength by being tested by life's hardships. Of course, this theodicy fails to take into account all of the suffering which appears to serve no useful 'soulbuilding' purpose. Suffering often destroys, rather than builds up, its victim, and those closest to him or her. ${ }^{5}$ In addition, it need hardly be mentioned that Hick's position finds little support in the Hebrew or Christian scriptures, so it is little wonder that his theodicy has not found more support among traditional Jews or Christians. ${ }^{6}$ That we

\footnotetext{
3 Dostoyevsky, The Brothers Karamazov, 283.

4 John Hick, Evil and the God of Love (San Francisco: Harper and Row, 1977), ix.

5 Hick, of course, understands this, but believes that even 'destructive' suffering will eventually be replaced by 'positive' suffering 'in other spheres beyond this world,' so that such an individual can reach the 'perfection intended for him by God.' Christianity at the Center (New York: Herder and Herder, 1970), 91.

6 This is not to say that the Bible sees no value in suffering. On the contrary, the apostle Paul often speaks of the necessity, even the positive quality, of suffering
} 
are perfected and 'made ready' for heaven via the soul-building process, rather than through the cross of Christ, is enough to render Hick's theodicy untenable to biblically-oriented Christians.

Current theistic treatments of suffering have been somewhat more realistic than Hick's, for they take into account the fact that suffering often serves no discernible purpose. For example, Wykstra has proposed what he calls the 'Parent Argument' to explain the existence of evil. he writes that 'our discerning most of God's purposes [when He permits evil to occur] are [sic] about as likely as the infant's discerning most of the parent's purposes [when the parent does things which seem inexplicably cruel to the child, even though they are for the child's benefit].' 7 Wykstra goes on to state that 'if our universe is created by God it is expectable that it would be deep; this is of course reason to think that if there are God-purposed goods, they would often be beyond our ken.' ${ }^{8}$ Alston writes in a similar vein when he argues that God may have a myriad of reasons for permitting evil occurrences which seem pointless to us:

Perhaps, unbeknownst to us ... suffering is necessary, in ways we cannot grasp, for some outweighing good of a sort with which we are familiar, e.g., supreme fulfillment of one's deepest nature. Or perhaps it is necessary for the realization of a good of which we as yet have no conception. ${ }^{9}$

Of course, the objections to the type of theodicy Wykstra and Alston advance are many. The thoughtful theist will surely wonder why the omnipotent God of the Bible cannot bring about the good he desires without permitting evil at all, or at least without permitting so much evil. And here, Ivan Karamazov again comes to mind, for what good can possibly result from the torture and murder of children? True enough, the apostle Paul's well-known statement, that God works all things together for good for those who love him, might be marshalled in defence of the writers' position. But this one statement is not detailed enough to ground a theodicy upon, and scripture does no lend anything like unequivocal support to the idea that suffering always

(i.e. Rom. 5:3-4, 2 Cor. 1:5-7). But suffering, apart from Christ's work on the cross, is never presented as the means whereby Christians find salvation. This is the primary weakness of Hick's Theodicy from a biblically-based Christian viewpoint.

7 Stephen John Wykstra, 'Rowe's Noseeum Argument from Evil', in The Evidential Argument from Evil, ed. Daniel Howard-Snyder (Bloomington: Indiana University, 1996), 129.

8 Wykstra, 'Rowe's Noseeum Argument from Evil', 140.

9 William P. Alston, 'The Inductive Argument from Evil', in The Evidential Argument from Evil, 109. 
produces benefits in the long run. Thus the anguished cry of the psalmists, who ask why God permits suffering and oppression to continue. Therefore, a biblical theist (not to mention an atheist!) certainly is entitled to find this view less than satisfying, especially when confronted with evil in his or her own life. God may indeed use suffering to bring about good, but, from our finite vantage point, this must forever remain speculation, not an explanation, for the evil we encounter in the world.

Clearly, the problem of evil which was so vividly made manifest in the Holocaust is not a new problem. It is an age-old problem: why does God allow innocent people to suffer at the hands of evil men, or at the whim of a seemingly indifferent world? In the case of the Holocaust, this puzzle was all the more baffling, since the victims were God's chosen people, while the perpetrators were devilish madmen who committed their crimes under the aegis of a perverted Christian cross, the Nazi swastika. As early as the mid-sixties, the Holocaust was already becoming the pivotal event in Jewish history in regards to how Jews should view God. Rabbi Richard Rubenstein could already make the following statement: 'We stand in a cold, silent, unfeeling cosmos, unaided by any purposeful power beyond our own resources. After Auschwitz, what else can a Jew say about God?'10 Rubenstein expressed alarm that so many of his fellow Jewish theologians had not realised that the event of Auschwitz had forever altered, indeed destroyed, the faith of the Jews which for 4,000 years had sustained them through untold persecutions and suffering: 'How can Jews believe in an omnipotent, beneficent God after Auschwitz?' "I Traditional Jewish theology had often sought to explain Jewish sufferings in light of the wrath of a holy and just God who was punishing His rebellious people for their sins. To view the Holocaust as yet another in a series of catastrophes imposed upon the hapless Jews by their God is 'too obscene' for Rubenstein to accept. ${ }^{12}$

But if Rubenstein had cause to wonder why more Jewish theologians had not come to view Auschwitz in the same way he did, the tide of opinion has drastically changed. Today, of course, it is commonplace for Jewish theologians to redefine God, as well as what it means to be Jewish, in light of the Holocaust. During a 4-day symposium on Jewish-Christian relations in New York City, Irving

10 Richard L. Rubenstein, After Auschwitz (Indianapolis: The Bobbs-Merrill Company, 1966), 152.

II Rubenstein, After Auschwitz, 153.

12 Rubenstein, After Auschwitz, 153. 
Greenberg said of the Holocaust that ' $[t]$ he cruelty and the killing raise the question whether even those who believe after such an event dare talk about God who loves and cares without making a mockery of those who suffered.' 13 Greenberg believes that it is the scope, the sheer magnitude of the evil which the Holocaust manifested, that forces theists to re-examine their traditional view of God. In the Holocaust, 'Limits were broken, restraints shattered, that will never be recovered, and henceforth mankind must live with the dread of a world in which models for unlimited evil exist.' 14

But it is not only Jewish theologians who now think this way. Christian thinkers, especially those engaged in the Jewish-Christian dialogue, have also adopted the Holocaust as the focal point for meaningful theological reflection. Clark Williamson is a Christian representative of this line of thought. And although he does not address the problem of evil per se, he is typical of many Christian thinkers for whom the Holocaust demands great theological change. He has written on the subject on anti-Semitism for many years, and treats the subject of Christian anti-Semitism, and the Jewish-Christian encounter in general, in his book $A$ Guest in the House of Israel: PostHolocaust Church Theology. The very name of the work implies that Christian theology vis-à-vis Judaism must take on a new face in a post-Holocaust world. Williamson writes that

we have stipulated one set of rules for doing Christian theology after Auschwitz: that we will beware any theological statement made after the Shoah [Holocaust] that is unchanged from how it was made before [the Shoah $]^{15}$

Williamson is not just talking about Jewish theological statements regarding Jewish views of God. Christians theology, too, must be radically altered to take into account the events of the Holocaust. For Williamson, the Holocaust was an event of such awful magnitude that even the most fundamental doctrines of the Christian faith (including the messiahship of Christ) must be rethought and, if need be, radically reinterpreted. Part of the reason for this is a certain amount of Christian complicity in the Holocaust: two millennia of Christian antiSemitism, while not causing the Holocaust directly, certainly helped pave the way for that tragic event. But it is the Holocaust itself, and

13 Irving Greenberg, 'Cloud of Smoke, Pillar of Fire', in Auschwitz: Beginning of a New Era?, ed. Eva Fleischner (New York: KTAV, 1977), 11.

14 Greenberg, 'Cloud of Smoke, Pillar of Fire', 14.

15 Clark M. Williamson, A Guest in the House of Israel: Post-Holocaust Church Theology (Louisville: Westminster/John Knox, 1993) 20. 
the sheer magnitude of the suffering it caused, which forces Williamson to radically reinterpret Christian dogma. Williamson desire to combat anti-Semitism is laudable. His recognition of Christian complicity in anti-Semitism is a hard truth of which all Christians must be made aware. But his willingness to sacrifice the essentials of the Christian faith in response to the evil which occurred in the Nazi death camps cannot be accepted by Christians for whom the New Testament still retains normative authority. Scripture, not experience (however horrendous that experience may be), must be the Christian's guide on matters of doctrine.

I wish in no way to underestimate the horror of the Holocaust. It was, without a doubt, one of the most demonic expressions of human evil the world has yet witnessed. As a Christian, it is all the more disturbing for me when I realise that the Nazis perpetrated their crimes in 'Christian' Germany, and that the rest of the 'Christian' world basically ignored what was happening in Germany until it was too uncomfortable to do otherwise. In fact, the Holocaust was, in some ways, the tragic culmination of centuries of Christian antiSemitism, as Williamson's book correctly points out.

What I do want to suggest is that the Holocaust, while certainly one of the most appalling examples of evil yet seen, is really no different, in terms of human suffering, from many other great tragedies which have befallen humanity. For example, one need only think of the Black Death, which killed one-third of Europe's population in the Middle Ages, or the religious wars which ravaged the Continent in the years following the Reformation. The sheer loss of life in both of these catastrophes is certainly comparable with the loss of life in the Holocaust. More current examples include the Taiping Rebellion of the 1850s, which killed 20 million, or Stalin's purges, which in one decade alone (1929-39) also destroyed as many as 20 million lives. The Chinese civil war which raged in the 1930's and 40's consumed somewhere between 34 and 62 million lives. ${ }^{16}$

And lest anyone object that these tragedies concerned the Gentile world, whereas the Holocaust was an unprecedented example of Jewish suffering, a quick review of the long, sad history of the Jewish people suggests otherwise. Paul Tillich once remarked that the Holocaust (Hebrew Shoah, or 'destructive storm') 'is only one storm in the whole history of Jewish life. You must teach it as part of the other persecutions: the Inquisition, the Middle Ages-they are all part

16 Steven T. Katz, The Holocaust in Historical Context Vol. I (New York: OUP), 66-67. 
of the story.' 17 The 'story', of course, began long before the Inquisition or the Middle Ages; the Hebrew Bible itself is ample witness to the tragic history of Jewish sufferings. Karl Barth notes that the tribulations of the Jews are 'described by almost every book of the Old Testament' ${ }^{18}$ Of course, neither Tillich nor Barth had any desire to underplay the sufferings caused by the Holocaust; they merely pointed out that persecution and suffering have always been at the core of Jewish existence, and that the Holocaust needs to be seen within that context, rather than an as aberration with no antecedents in Jewish history.

A brief examination of some statistics from Jewish history may help to put the Holocaust in its proper historical perspective. For example, the Assyrian Conquests (734-701 BC), while not as costly as the Holocaust in terms of the actual number of Jews killed, nevertheless were 'nearly as demographically repercussive in percentage terms [that is, Jews killed and/or uprooted from their land] as the Sho'ah.' 19 A similar case can be made for The Babylonian Conquest $(597-86 \mathrm{BC})^{20}$ When we come to the Jewish revolt against Rome which culminated in the destruction of Jerusalem in AD 70, the actual number of Jews killed is far higher, which Roman historian Tacitus numbers at 600,000 , while Jewish historian Josephus places the number at 1.1 million. ${ }^{21}$ Of course, the sheer number of Jews who perished in the Holocaust was higher than in any of these earlier tragedies, but is there really any meaningful qualitative difference between the one million Jewish victims of Rome and the 6 million Jews who died in the Holocaust? Numbers alone cannot establish the Holocaust as unique in the history of Jewish tragedy. ${ }^{22}$ Are we going to affirm that God is just if he allows six innocent persons to die, but condemn him as unjust (and revise our theology accordingly) if he permits six, sixty, or six million to perish?

17 Quoted in Albert H. Friedlander, 'A Final Conversation with Paul Tillich', Out of the Whirlwind, 516.

18 Karl Barth, Dogmatics in Outline (ET G.T. Thompson; London: SCM, 1949) 78. Barth is often criticised for attributing Jewish suffering to their unfaithfulness to God, but here he is only following in the footsteps of the Jewish prophets of scripture, who constantly berate their fellow Jews for their lack of faith and predict dire consequences if they do not repent.

19 Barth, Dogmatics in Outline, 68-73.

20 Barth, Dogmatics in Outline, 73-76.

21 Barth, Dogmatics in Outline, 76-77.

22 Barth, Dogmatics in Outline, 83-84. 
If none of those events described above led to the abandonment of traditional views of God and evil, why should the Holocaust? It is certainly true that our century has seen a great amount of evil, and the Holocaust, along with the battlefield slaughter of two world wars, is largely responsible for this. But surely this is not so different from what has occurred in previous centuries. C.S. Lewis, responding to the alleged 'new urgency' brought about by modern man's recognition of the riddle of evil, cogently remarks, 'what new urgency?... it is no more urgent for us than for the great majority of monotheists all down the ages. The classic expositions of the doctrine that the world's miseries are compatible with its creation and guidance by a wholly good Being come from Boethius waiting in prison to be beaten to death and from St. Augustine meditating on the sack of Rome. ${ }^{23}$ For all the talk of a new theological age being ushered in by the Holocaust, for all those who claim that nothing in theology can ever again be the same after Auschwitz, Lewis' statement that ' $[\mathrm{t}] \mathrm{he}$ present [evil] state of the world is normal' 24 may be of little comfort, but it is clearly the truth.

When one ponders the enigma of evil from a biblical perspective, the book which comes to mind is, of course, Job. For centuries, Job has provided Jews and Christians with, if not an explanation for evil, at least a picture of a world where God is fully in charge, despite evidence which may sometimes seem to imply the contrary. Yet Rabbi Rubenstein has said that ' $[t]$ he agony of European Jewry cannot be likened to the testing of Job. ${ }^{25} \mathrm{He}$ says this because the evil of the German death camps seems so purposeless that to see God's hand in it defies credulity. But cannot the same be said for the case of Job? Contrary to what Rubenstein says, what happened to Job is analogous to what happened to six million Jews during World War II. In both instances, people were made to suffer horribly, and in both cases, the point of this suffering is impossible to discern. After Job's troubles have befallen him, God speaks to him from the whirlwind, but what kind of answers does God give? Does he explain why evil and suffering occur? Does he explain why he, as an all-powerful God, allows such things? No. He does, however, impress upon Job the limits of Job's understanding of such things. What Job does learn here is that the ways of God are beyond the understanding of men, and that

23 C.S. Lewis, 'Evil and God', God in the Dock, ed. Walter Hooper (Grand Rapids: Eerdmans, 1976), 22.

24 Lewis, 'Evil and God', 22.

25 Rubenstein, After Auschwitz, 153. 
sometimes men and women of faith can only accept, in ignorance and humble piety, the ways of God toward his creatures. Thus, the only 'answer' that the author of Job gives to the dilemma of evil is really no answer at all, but rather an admission of the limits of human understanding. After God chastises Job, Job confesses that 'I spoke of things I did not understand, things too wonderful for me to know' (42:3), and 'I despise myself and repent in dust and ashes' (42:6).

Of course, the case can be made that the sufferings of Job were only the sufferings of one man (and, of course, his children who were killed) and the sufferings of one man, however horrific, cannot be compared to the sufferings of six million. But this is a spurious argument. ${ }^{26}$ If God allows one to suffer unjustly, or millions to suffer unjustly, the basic problem is the same-an all-loving, all-powerful God who allows what seems to be unmerited suffering. One could also say that despite Job's sufferings, all was made well in the end, for Job was compensated by God for all of the pain and loss he incurred. But is this really true? Can the pain of losing one's children be remedied simply by having more children? And what about the fundamental question of God allowing Job's unwarranted suffering in the first place? And if we grant that sufferings in the past are overshadowed by blessings to come, then surely many who suffered during the Holocaust have since been 'reimbursed', for many of those who lived through the ordeal are now happily married, have large families, material blessings, etc. Simply put, a purely 'rational' God who behaves only in ways which are acceptable and understandable to us is not the God we find described in either the Hebrew or the Christian scriptures. His ways are not our ways, the Hebrew scriptures tell us. In the end, the Holocaust, like any instance of evil or suffering which has no apparent good purpose, can dishearten even the most devout among us. But I think a saner, certainly more honest (and certainly more biblical) approach is to simply admit that we do not know why such things happen. Redefinitions of who God is and how he operates do nothing to solve the problem. Our theology must be based on revelation, not speculation or experience.

26 This point is well-made by C.S. Lewis in the following quotation, which is not concerned with the Holocaust per se, but with the general idea that human suffering is somehow worse when many persons, rather than one, suffer: ' $[t]$ here is no such thing as a sum of suffering, for no one suffers it. When we have reached the maximum that a single person can suffer, we have, no doubt, reached something very horrible, but we have reached all the suffering there ever can be in the universe. The addition of a million fellow-sufferers adds no more pain.' The Problem of Pain (New York: Macmillan Publishing, 1962), 116. 
Interestingly enough, the criterion of human experience (rather than divine revelation), which so many theologians have used as the basis for reassessing their understanding of God and evil in the wake of the Holocaust, does not seem to apply in the same way to the establishment of the state of Israel in the late 1940s. While numerous theologians have revised their theology due to the Shoah, there seems to be far less of a corresponding appreciation of the benevolence of God as manifested in the creation of the modern Jewish state. But the revisionists are here confronted with a problem: if human experience is to determine what we believe about God, then surely the creation of a Jewish homeland after 2,000 years of Jewish homelessness and persecution must be taken more seriously. Add to this the fact that Israel has repelled every military attack levelled against it, often with near-miraculous efficiency against overwhelming odds. These events, it seems to me, are just as momentous as the Holocaust, yet they have not resulted in the same kind of sea-change in theological thinking as has the Holocaust.

In the New Testament, Paul tells us that God works all things together for good for those that love Him; the scriptures seem to affirm in several places that God is in control of all that occurs, be it good or evil.27 Just how this can be squared with the traditional doctrines of God's omnipotence and omnibenevolence cannot always be understood, but only accepted in the humble faith which is the very essence of biblical theism. A recent article rightly points out that, to be a biblical theist, is to accept the mystery of suffering: "if theism is true we would expect that there would be inscrutable evil. Indeed, a little reflection shows there is no reason to think we could so much as

27 This traditional Christian view concerning evil, dominant since the time of Augustine, has recently been challenged by Gregory Boyd, in God at War: The Bible and Spiritual Conflict (Downers Grove, IL: InterVarsity, 1997). Boyd maintains that the viewpoint of scripture, as well as of the early church fathers, is that all evil in the world can ultimately be attributed to Satan and the realm of the demonic. Thus, evil forms no part of God's 'grand design' for the universe. Rather, evil is something God is actively combating. Boyd's book is very persuasive at points, especially when he presents his case for what he terms the 'warfare worldview' of scripture (i.e. God, the cause of all good, vs. Satan, the cause of all evil). Modern Christians need to be reminded that this worldview is indeed part of the Bible, and that it is especially prevalent in the NT, where Christ is often presented as the destroyer of the devil's works. However, for our purposes here, Boyd's thesis does not alter the fundamental question of why God permits such appalling evil. Surely he is more powerful than Satan, and thus could put an end to him, and his evil deeds, at any time. Surely he could have at least 'temporarily restrained' him to prevent the Holocaust! 
grasp God's plans here, even if he proposed to divulge them to us.' 28 It is faith in the face of such inscrutable evil which has sustained the Jewish people through 4,000 years of assorted tragedies, and it is this faith which still sustains many of them, despite the horrors of the Shoah. In fact, the history of Jewish faith in their God has been nothing short of amazing. The Jews collectively have never abandoned their faith in the God of scripture, despite the tragedies of 4,000 years of history. The amazing perseverance of this small group of people, despite the evil machinations of some of histories greatest powers, has, of course, been pointed out before, and it led Barth to declare this Jewish tenacity as the one sure proof of God's existence. Barth liked to quote a conversation between Frederick the Great and his personal physician, Zimmermann: "'Zimmermann, can you name me a single proof of the existence of God?" And Zimmermann replied, "Your majesty, the Jews!"' 29 These words could have just as easily been uttered after, rather than before, the Holocaust occurred.

Earlier I quoted Rabbi Rubenstein: 'We stand in a cold, silent, unfeeling cosmos, unaided by any purposeful power beyond our own resources. After Auschwitz, what else can a Jew say about God?'30 But surely this statement could have been made, just as appropriately, after the Assyrian or the Babylonian conquests, or after the destruction of Jerusalem by the Romans in AD 70. It could have been made, just as appropriately, when any terrible tragedy befalls any one of us in our daily lives. And perhaps the best answer to this question, whenever it be asked, is that given by Job: 'Though he slay me, yet will I hope in him' (13:15). This was Job's faith as he suffered his unwarranted afflictions, and it has been the faith of untold numbers of Jews and Christians through the ages, whether facing religious persecution or facing the general sorrow and suffering which comes upon all at one point or another. The answer God gives from the whirlwind may not be especially satisfactory, especially when we are faced with horrible evil and suffering which seem entirely pointless. But this has always been a problem for the religious Jew and Christian (indeed, it has always been the strongest weapon in the atheist's arsenal). But it is intellectually dishonest to act as though this problem was not just as intractable millennia before the Holocaust occurred, and that it would not be just as vexing had the Holocaust never happened.

28 Alvin Plantinga, 'Epistemic Probability and Evil', in The Evidential Argument from Evil, 76.

29 Barth, Dogmatics in Outline, 75.

30 Rubenstein, After Auschwitz, 152. 